\title{
Evaluation of Sense of Smell in Onychomycosis Patients Receiving Terbinafine Treatment
}

\author{
Terbinafin Tedavisi Alan Onikomikoz Hastalarında Koku Duyusunun Değerlendirilmesi
}

\author{
Mualla POLAT ${ }^{1}$ \\ (D) 0000-0001-9226-5134 \\ Tekden KARAPINAR ${ }^{2}$ \\ (D) 0000-0003-3795-0731 \\ Belgin KÜÇÜKYANGÖZ ${ }^{1}$ \\ (D) 0000-0003-3877-918X \\ Yusuf Özgür BİÇER ${ }^{3}$ \\ (i) 0000-0002-4646-7250 \\ Özge UZUN ${ }^{4}$ \\ (D) 0000-0003-1380-350X \\ Tuna SEZER ${ }^{5}$ \\ (D) 0000-0002-6861-2869
}

\begin{abstract}
${ }^{1}$ Department of Dermatology, Bolu Abant İzzet Baysal University, Faculty of Medicine, Bolu, Turkey

${ }^{2}$ Dermatology Clinic, Bingöl State Hospital, Bingöl, Turkey

${ }^{3}$ Department of Otorhinolaryngology, Bolu Abant İzzet Baysal University, Faculty of Medicine, Bolu, Turkey ${ }^{4}$ Department of Pharmacology, Arel University Faculty of Medicine, İstanbul, Turkey

${ }^{5}$ Dermatology Clinic, İzzet Baysal State Hospital, Bolu, Turkey
\end{abstract}

\section{Corresponding Author Sorumlu Yazar \\ Mualla POLAT \\ polatmualla@gmail.com}

Received / Gelis Tarihi : 15.10.2021 Accepted / Kabul Tarihi : 05.12.2021 Available Online /

Çevrimiçi Yayın Tarihi : 13.12.2021

\begin{abstract}
Aim: The most common side effects of terbinafine are gastrointestinal symptoms. Loss of taste and smell side effects are presented in a small number of case reports. We aimed to measure the effect of terbinafine on the sense of smell and the degree of change in the sense of smell in this study.

Material and Methods: Odor identification test (OIT), odor threshold test (OTT), and odor discrimination test (ODT) were applied to the patients treated with terbinafine and the control group. It was applied with "Sniffin Sticks" test pens. Smell test was performed on the patient group just before the start of terbinafine treatment and at the end of 3 months of treatment. Results: There was no statistical difference between the patient and control groups in terms of age $(\mathrm{p}=0.991)$ and gender $(\mathrm{p}=0.811)$. There was no statistical difference when the initial odor tests of the patient group and the control group were compared. The OIT value of the patient group was $10.15 \pm 1.43$ at the beginning and $10.10 \pm 1.15$ at the end of the treatment $(\mathrm{p}=0.743)$. The OTT values were $6.23 \pm 1.08$ at the beginning and $6.21 \pm 0.85$ at the end of the treatment $(p=0.811)$. The ODT values were $9.71 \pm 1.44$ at the beginning and $9.69 \pm 1.34$ at the end of the treatment $(\mathrm{p}=0.767)$. There was no statistical difference in the results of the tests performed at the beginning and end of the treatment.

Conclusion: There was no adverse effect on the sense of smell associated with the use of systemic terbinafine treatment for 3 months.

Keywords: Terbinafine; onychomycosis; Sniffin'Sticks test; odor.

ÖZ

Amaç: Terbinafinin en sık karşılaşılan yan etkileri gastrointestinal şikayetlerdir. Tat ve koku kaybı yan etkisi ise az sayıda vaka sunumunda bildirilmiş̧ir. Bu çalışmadaki amacımız terbinafinin koku duyusu üzerine etkisini ve koku duyusundaki değişimin derecesini ölçmektir. Gereç ve Yöntemler: Terbinafin tedavisi başlanan hastalara ve kontrol grubuna koku tanımlama testi (KTT; odor identification test, OIT), koku duyarlılık testi (KDT; odor threshold test, OTT) ve koku ayırım testi (KAT; odor discrimination test, ODT) uyguland. Koku testi "Sniffin Sticks" test kalemleri ile yapıldı. Hasta grubuna koku testi terbinafin tedavisi başlamadan hemen önce ve 3 aylık tedavi süresinin sonunda yapıldı.

Bulgular: Hasta ve kontrol grupları arasında yaş $(\mathrm{p}=0,991)$ ve cinsiyet $(\mathrm{p}=0,811)$ açısından istatistiksel olarak anlamlı bir fark saptanmadı. Hasta grubunun başlangıç koku testleri ve kontrol grubunun koku testleri karşılaştırıldığında da aralarında istatistiksel olarak anlamlı bir fark yoktu. Hasta grubunun KTT değeri tedavi başlangıcında $10,15 \pm 1,43$ ve tedavi sonunda ise $10,10 \pm 1,15$ olarak saptand $1(\mathrm{p}=0,743)$. KDT değerleri tedavi başlangıcında $6,23 \pm 1,08$ ve tedavi sonunda ise $6,21 \pm 0,85$ olarak tespit edildi $(\mathrm{p}=0,811)$. KAT değerleri tedavi başlangıcında $9,71 \pm 1,44$ ve tedavi sonunda ise $9,69 \pm 1,34$ olarak saptandı $(p=0,767)$. Tedavi başında ve sonunda yapılan test sonuçlarında istatistiksel olarak anlamlı bir fark yoktu.

Sonuç: Sistemik terbinafin tedavisinin 3 ay süreyle kullanımına bağlı olarak koku duyusu üzerinde herhangi bir yan etki tespit edilmemiştir.

Anahtar kelimeler: Terbinafin; onikomikoz; Sniffin'Sticks tes; koku.
\end{abstract}




\section{INTRODUCTION}

Terbinafine is a highly lipophilic synthetic allylamine antifungal drug that is widely used in the treatment of cutaneous dermatophyte infections. It has been used in topical and systemic forms since $1991(1,2)$. It shows its effect by inhibiting the squalene epoxidase enzyme. It is an easily tolerated, effective agent used systemically for 3 months without interruption in the treatment of onychomycosis (3). Common side effects of terbinafine include gastrointestinal side effects such as abdominal pain and nausea (2). Skin reactions and cholestatic hepatitis are among the rare side effects that can be seen. In addition, loss of taste and smell has been reported among the rare side effects $(4,5)$.

Loss of taste and smell are often overlooked as they are not life-threatening disorders, but they are senses that significantly affect quality of life. Numerous studies have been performed on the evaluation of olfactory functions and the conditions under which these functions are affected (6-8). Two types of tests are used for odor measurement: psychophysical (subjective) tests and electrophysiological (objective) tests. Psychophysical tests include the odor threshold test (OTT), the odor discrimination test (ODT), and the odor identification test (OIT). Sniffin' Sticks is a widely used psychophysical test. It has some advantages such as long shelf life, reusability, and relatively short application time (9).

In the literature, there are some studies which measuring the effect of terbinafine on the sense of taste, but there is no large-scale study investigating the effect on the sense of smell (4,10-13). We aimed to measure the effect of terbinafine that is commonly used drug in the treatment of onychomycosis on the sense of smell and the degree of change in the sense of smell.

\section{MATERIAL AND METHODS}

This prospective study was approved by Bolu Abant İzzet Baysal University Clinical Research Ethics Committee with the decision numbered 2017/84 and dated 14.09.2017, and was carried out between March 2018 and March 2019. The Sniffin Sticks Test (Burgart Medical Technology, Wedel, Germany) is a simple, easy-to-apply, standardized, and quantitative odor test. Sniffin Sticks Test was applied to the patients who diagnosed with onychomycosis and started on $250 \mathrm{mg} /$ day terbinafine treatment due to onychomycosis and to the control group. The odor test was performed just at the start of terbinafine treatment and at the end of 3 months of treatment. All participants signed a written informed consent.

\section{Patient Selection}

The study was made with a patient group that older than 18 years old and younger than 65 years of age who were diagnosed with onychomycosis and started systemic terbinafine treatment and a control group which consisting of similar age and gender healthy volunteers. Before the patients and healthy volunteers were included in the study, psychiatric diseases such as depression, schizophrenia, alcoholism; drug intaking such as metronidazole, amphotericin B, captopril, ethacrynic acid, codeine; obstructive nasal and sinus disease, upper respiratory tract infection; surgical interventions such as total laryngectomy, previous head trauma, rhinoplasty, anterior skull base surgery, old age were questioned. Patients with normal examinations were included in the study. A total of 50 patients and 50 healthy volunteers were included in the study.

Application of the Sniffin' Sticks Test

Odor Sensitivity Test, Smell Discrimination Test, and Smell Identification Test were applied with standardized odor test "Sniffin Sticks" test pens under appropriate conditions to the patients and control group (Figure 1). Sniffin' sticks odor test was applied in a quiet and wellventilated room, holding the tip of the pens $2 \mathrm{~cm}$ away from the nostrils and sniffing for 3-4 seconds. The patients were warned not to eat or drink anything at least one hour before the test.

\section{Odor Identification Test (OIT)}

The Identification test is a test that measures the correct identification of odors. It was made with blue cap pens numbered 1 to 16 with black markings (Figure 1A). Sixteen common odors (orange, leather, cinnamon, mint, banana, lemon, licorice, naphtha oil, garlic, coffee, apple, clove, pineapple, rose, anise, fish) with four choices were presented. Subjects were free to sample the odors as often as necessary to make a decision. Total score ranged between 0 and 16 .

\section{Odor Threshold Test (OTT)}

Threshold test shows that how intensely the patient perceives the odor. It was made with a total of 48 pens which have three different colors and labeled with red, numbered from 1 to 16 (Figure $1 \mathrm{~B}$ ). While the number 1 of the pens contain odor (n-butanol) at the highest concentration, the odor concentration decreases as the number on the pens increases. Each of the triple pens was sniffed by the patient at intervals of approximately 5 seconds. This is only one item of the three (red cap pen) contains the odor, other two (blue and green top pens) contain diluent. The patient was wanted to find the pen that smelled different from the other two. The test was completed by progressing to the lowest concentration which the patient could not smell. Total score ranged between 0 and 16 .

\section{Odor Discrimination Test (ODT)}

The Discrimination test measures the ability to distinguish odors from each other. It was made with a total of 48 pencils in three different colors, labeled with green, numbered 1 to 16 (Figure 1C). Three different colored pencils of the same number were smelled to the patient at 5-second intervals. Two of the pens represented the same smell, while the green-capped pen represented a different smell. The patient was asked to know what is different between the 3 smells. Total score ranged between 0 and 16 .

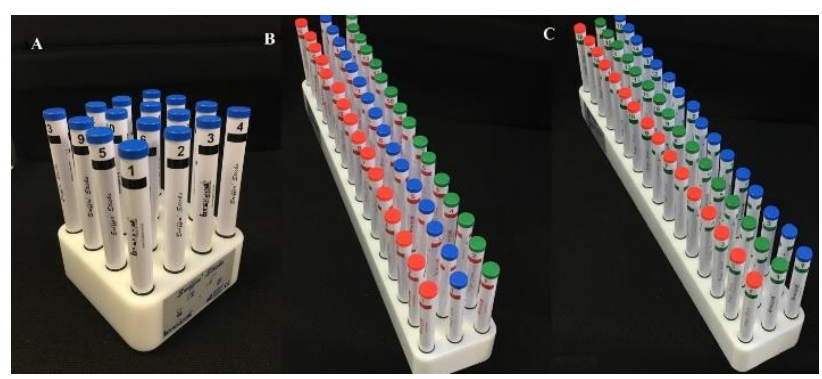

Figure 1. The Sniffin Sticks Test, A. Odor identification test pens, B. Odor threshold test pens, C. Odor discrimination test pens 
The sum of these three scores gives the overall threshold-discrimination-identification score (TDI). Subjects with a TDI score 48-31 were considered to have a normal olfactory function (normosmia); subjects with a TDI score of 30-16 were considered to have decreased olfactory function (hyposmia); and subjects with a TDI score $\leq 15$ were considered to have loss of olfactory function (anosmia).

\section{Statistical Analysis}

The Statistical Package for Social Sciences (SPSS, Chicago, IL) for Windows, version 22.0 program was used for statistical analysis. Descriptive statistics are given with mean and standard deviation for numerical variables, and numbers and percentages for categorical variables. Shapiro-Wilk test was used for the assumption of normality. Independent samples t test was used to compare the groups in terms of numerical variables. Pearson chisquare test was used in the analysis of categorical variables. The comparison of the measurements which before and after the treatment in the patient group was made with the Paired samples t-test. In all tests, a value of $\mathrm{p}<0.05$ was accepted as statistical significance.

\section{RESULTS}

A total of 50 patients and 50 healthy volunteers were included in the study. One of the patients did not want to continue the test because of the nausea due to the fishy smell in the test performed after the treatment. Therefore, the study was completed with 49 patients and 50 healthy volunteers. There were $19(38.8 \%)$ female and $30(61.2 \%)$ male in the patient group. Healthy volunteers consisted of $20(40.0 \%)$ females and $30(60.0 \%)$ males. The age of the patients was between 25-64 years and the mean age was $47.15 \pm 10.88$ years. The ages of the volunteers were between 23-64 years and the mean age was $47.12 \pm 9.46$ years. There was no statistically significant difference between the patient and control groups in terms of age $(p=0.991)$ and gender (0.811). In addition, no difference was observed in the education level $(\mathrm{p}=0.994)$, smoking $(\mathrm{p}=0.278)$ and alcohol using of the patient and control groups (Table 1). When the initial odor tests of the patient group and the odor tests of the control group were compared, no statistically significant difference was found in terms of OIT $(\mathrm{p}=0.874)$, OTT $(\mathrm{p}=0.903)$, and ODT $(\mathrm{p}=0.983)$. The OIT value of the patient group was $10.15 \pm 1.43$ at the beginning and $10.10 \pm 1.15$ at the end of the treatment $(p=0.743)$. The OTT value was $6.23 \pm 1.08$ at the beginning and $6.21 \pm 0.85$ at the end of the treatment $(\mathrm{p}=0.811)$. The ODT value was $9.71 \pm 1.44$ at the beginning and $9.69 \pm 1.34$ at the end of the treatment $(\mathrm{p}=0.767)$. There was no statistically significant difference in the results of the odor test performed at the beginning and end of the treatment (Table 2).

\section{DISCUSSION}

The sense of smell can be categorized in three ways: normal (normosmic), little (hyposmic) and not perceiving at all (anosmic). There may also be disorders of the sense of smell, such as dysosmia (impaired perceived quality of smell) and phantom smell (olfactory hallucinations, phantosmia) without an obvious olfactory stimulus (14). Nasal and sinus diseases, upper respiratory tract infection, head trauma, smoking and neurodegenerative diseases are possible causes of smell disorders. Also, some anticonvulsant
Table 1. Characteristics of the patient and control groups

\begin{tabular}{lccc}
\hline & $\begin{array}{c}\text { Patient } \\
(\mathbf{n = 4 9 )}\end{array}$ & $\begin{array}{c}\text { Control } \\
(\mathbf{n = 5 0})\end{array}$ & $\mathbf{p}$ \\
\hline Age (year), mean \pm SD & $47.15 \pm 10.88$ & $47.12 \pm 9.46$ & 0.991 \\
Gender, n (\%) & & & \\
$\quad$ Male & $30(61.2)$ & $30(60.0)$ & 0.811 \\
$\quad$ Female & $19(38.8)$ & $20(40.0)$ & \\
Education Status, n $(\%)$ & $10(20.4)$ & $10(20.0)$ & \\
$\quad$ Middle School & $22(44.9)$ & $23(46.0)$ & 0.994 \\
$\quad$ High school & $17(34.7)$ & $17(34.0)$ & \\
$\quad$ University & $15(30.6)$ & $16(32.0)$ & 0.278 \\
Smoking, n $(\%)$ & $10.15 \pm 1.43$ & $10.10 \pm 1.28$ & 0.874 \\
OIT, mean \pm SD & $6.23 \pm 1.08$ & $6.20 \pm 0.94$ & 0.903 \\
OTT, mean \pm SD & $9.71 \pm 1.44$ & $9.71 \pm 1.34$ & 0.983 \\
ODT, mean \pm SD & $26.06 \pm 2.21$ & $26.04 \pm 2.05$ & 0.960 \\
TDI, mean \pm SD &
\end{tabular}

SD: standard deviation, OIT: odor identification test, OTT: odor threshold test, ODT: odor discrimination test, TDI: threshold-discrimination-identification

Table 2. Odor test results at the beginning and end of treatment

\begin{tabular}{lccc}
\hline & $\begin{array}{c}\text { Before } \\
\text { treatment }\end{array}$ & $\begin{array}{c}\text { After } \\
\text { treatment }\end{array}$ & p \\
\hline OIT, mean \pm SD & $10.15 \pm 1.43$ & $10.10 \pm 1.15$ & 0.743 \\
OTT, mean \pm SD & $6.23 \pm 1.08$ & $6.21 \pm 0.85$ & 0.811 \\
ODT, mean \pm SD & $9.71 \pm 1.44$ & $9.69 \pm 1.34$ & 0.767 \\
TDI, mean \pm SD & $26.06 \pm 2.21$ & $26.00 \pm 2.22$ & 0.666 \\
\hline
\end{tabular}

SD: standard deviation, OIT: odor identification test, OTT: odor threshold test, ODT: odor discrimination test, TDI: threshold-discrimination-identification

and antidepressant drugs cause smell and taste disorders. Dihydropyridine group calcium channel blockers, beta blockers, ciprofloxacin, diltiazem, doxycycline, enalapril, lovastatin and methotrexate are among the drugs that cause loss of smell (15).

Mechanisms that underlying drug-induced taste and/or smell alteration can be divided into two groups as primary, resulting from the direct effect of the drug and secondary, resulting from the indirect effect of the drug. Primary mechanisms include drug-receptor interaction; disruption of action potential propagation in the cell membrane of afferent and efferent neurons; altering neurotransmitter function; changes in brain regions associated with sensory coding and modulation. Limitation of access of chemicals to sensory receptors (dry mucosa, increased nasal congestion, closure of taste pores, inflammation or infections) and changes in the chemical or ionic environment in the environment of sensory receptors are secondary mechanisms (10). There was no disease that would cause loss of smell in the patients included in our study. They were also not using any other medication.

Although the sense of smell is little studied in dermatology practice, it is an important sense that directly affects the quality of life (16). Sniffin' Sticks test is widely used in Europe to evaluate the sense of smell. This test was developed by Hummel et al. (17) and Kobal et al. (18) and includes one test in the threshold range (determination of the odor detection threshold for n-butanol) and two tests above the threshold (discrimination and identification). The advantage of Sniffin' Sticks test kit is that it is reusable and easy to apply. It is emphasized that it is a modern, 
standard odor test that can be used for odor testing (19). However, cultural differences complicate the application of OITs in different countries. Because odor identification is highly dependent on familiarity with the odors tested. It is observed that the Sniffin' Sticks test performs well when applied cross-culturally and Tekeli et al. (20) reported that this test will be applied to Turkish patients without any additional changes in their study. In our study, we used the Sniffin' Sticks test that suitable for Turkish society. In addition, we found no statistical difference between the test baseline values, the demographic characteristics, educational status, smoking/alcohol use of the patient group in whom terbinafine treatment was initiated and the values of the healthy control group.

Terbinafine, a drug of the allylamine group, is an effective drug against dermatophyte, cryptococcal and other fungal infections (21). Terbinafine is a drug with an oral absorption of over $70 \%$ and well tolerated. Terbinafine is a lipophilic drug that concentrates on the dermis, epidermis, and adipose tissue. It is metabolized in the liver and often excreted by the kidneys (4). Terbinafine inhibits the enzyme squalene epoxidase, which is responsible for the production of sterols necessary to protect the integrity of the cell membrane. In humans, the squalene epoxidase enzyme is involved in the biosynthesis of cholesterol. Therefore, it has been suggested that terbinafine may alter the structure or function of neurons by interfering with the cholesterol pathway (22).

Side effects were reported in $2.7 \%$ of patients using terbinafine. The most common side effects are generalized pustulosis, urticaria, gastrointestinal symptoms, loss of taste and liver toxicity. Drug-induced lupus erythematosus (often subacute cutaneous lupus erythematosus) and exacerbation of psoriasis are other rare side effects (23-25). In the literature, it is reported that the rate of taste loss due to terbinafine is $0.6-2.8 \%$. Case reports show that taste loss occurs 4-6 weeks after drug use. Although long-term taste losses have been reported, it was reported that recovering in sense of taste occurs at 4 months after the drug was discontinued (13). Although there is a close relationship between taste and smell sensory disorders, olfactory changes have not been evaluated in patients with taste disorders (13). Terbinafine-induced loss of smell has been reported very rarely in the literature (10). Tuccori et al. (10) reported that 15 of 17 patients had taste disorders, three patients had parosmia, and two of them had parosmia without taste disorders. However, Doty et al. (13) reported that there was no change in the sense of smell in patients using terbinafine despite having taste disorders. In our study, it was determined that there was no statistically significant difference in sense of smell in patients using terbinafine.

The small number of patients and the fact that taste changes were not evaluated are the limitations of this study.

\section{CONCLUSION}

In conclusion, our study, in which we used the Sniffin' Sticks test kit, which is considered a reliable odor test, showed that systemic terbinafine treatment used for 3 months did not cause any side effects on the sense of smell and this drug can be used safely. However, the results of the study should be supported by studies with a larger number of patients.
Ethics Committee Approval: The study was approved by the Clinical Researches Ethics Committee of Bolu Abant İzzet Baysal University (14.09.2017, 84).

Conflict of Interest: None declared by the authors.

Financial Disclosure: None declared by the authors.

Acknowledgements: None declared by the authors.

Author Contributions: Idea/Concept: MP, TK, TS; Design: MP, TK, YÖB; Data Collection/Processing: MP, TK, BK, YÖB, TS; Analysis/Interpretation: MP, TK, ÖU; Literature Review: MP, TK, BK; Drafting/Writing: MP, TK, BK; Critical Review: MP, ÖU.

\section{REFERENCES}

1. Balfour JA, Faulds D. Terbinafine: a review of its pharmacodynamic and pharmacokinetic properties and therapeutic potential in superficial mycoses. Drugs. 1992;43(2):259-84.

2. Villars VV, Jones TC. Special features of the clinical use of oral terbinafine in the treatment of fungal diseases. Br J Dermatol. 1992;126(Suppl 39):61-9.

3. Gupta AK, Paquet M, Simpson F, Tavakkol A. Terbinafine in the treatment of dermatophyte toenail onychomycosis: a meta-analysis of efficacy for continuous and intermittent regimens. J Eur Acad Dermatol Venereol. 2013;27(3):267-72.

4. Bong JL, Lucke TW, Evans CD. Persistent impairment of taste resulting from terbinafine. $\mathrm{Br} \mathrm{J}$ Dermatol. 1998;139(4):747-8.

5. Beutler M, Hartmann K, Kuhn M, Gartmann J. Taste disorders and terbinafine. BMJ. 1993;307(6895):26.

6. Thuerauf N, Reulbach U, Lunkenheimer J, Lunkenheimer B, Spannenberger R, Gossler A, et al. Emotional reactivity to odors: olfactory sensitivity and the span of emotional evaluation separate the genders. Neurosci Lett. 2009;456(2):74-9.

7. Aschenbrenner K, Scholze N, Joraschky P, Hummel T. Gustatory and olfactory sensitivity in patients with anorexia and bulimia in the course of treatment. $\mathbf{J}$ Psychiatr Res. 2008;43(2):129-37.

8. Swiecicki L, Zatorski P, Bzinkowska D, SienkiewiczJarosz H, Szyndler J, Scinska A. Gustatory and olfactory function in patients with unipolar and bipolar depression. Prog Neuropsychopharmacol Biol Psychiatry. 2009;33(5):827-34.

9. Cingoz ID, Kizmazoglu C, Guvenc G, Sayin M, Imre A, Yuceer N. Evaluation of the olfactory function with the "Sniffin' Sticks" test after endoscopic transsphenoidal pituitary surgery. J Craniofac Surg. 2018;29(4):1002-5.

10. Tuccori M, Lapi F, Testi A, Ruggiero E, Moretti U, Vannacci A, et al. Drug-induced taste and smell alterations: a case/non-case evaluation of an Italian database of spontaneous adverse drug reaction reporting. Drug Saf. 2011;34(10):849-59.

11. Lemont H, Sabo M. Terbinafine-associated taste disturbance with normal taste threshold scores. J Am Pediatr Med Assoc. 2001;91(10):540-1.

12. Stricker BH, Van Riemsdijk MM, Sturkenboom MC, Ottervanger JP. Taste loss to terbinafine: a case control 
study of potential risk factors. Br J Clin Pharmacol. 1996;42(3):313-8.

13. Doty RL, Haxel BR. Objective assessment of terbinafine induced taste loss. Laryngoscope. 2005;115(11):2035-7.

14. Boesveldt S, Postma EM, Boak D, Welge-Luessen A, Schöpf V, Mainland JD, et al. Anosmia-A clinical review. Chem Senses. 2017;42(7):513-3.

15. Horger S, Kandrac S, Longyhore DS. Taste and smell disturbance resulting from midodrine. J Pharm Pract. 2016;29(6):571-3.

16. Hummel T, Nordin S. Olfactory disorders and their consequences for quality of life. Acta Otolaryngol. 2005;125(2):116-21.

17. Hummel T, Sekinger B, Wolf SR, Pauli E, Kobal G. 'Sniffin' sticks': olfactory performance assessed by the combined testing of odor identification, odor discrimination and olfactory threshold. Chem Senses. 1997;22(1):39-52.

18. Kobal G, Klimek L, Wolfensberger M, Gudziol H, Temmel A, Owen CM, et al. Multicenter investigation of 1,036 subjects using a standardized method for the assessment of olfactory function combining tests of odor identification, odor discrimination, and olfactory thresholds. Eur Arch Otorhinolaryngol. 2000;257(4):205-11.
19. Landis BN, Hummel T. New evidence for high occurrence of olfactory dysfunctions within the population. Am J Med. 2006;119(1):91-2.

20. Tekeli H, Altundağ A, Salihoğlu M, Cayönü M, Kendirli MT. The applicability of the 'Sniffin' Sticks" olfactory test in a Turkish population. Med Sci Monit. 2013;19:1221-6.

21. Yan J, Wang X, Chen S. Systematic review of severe acute liver injury caused by terbinafine. Int J Clin Pharm. 2014;36(4):679-83.

22. Ryder NS. Terbinafine: mode of action and properties of the squalene epoxidase inhibition. Br J Dermatol. 1992;126(Suppl 39):2-7.

23. Koch A, Tchernev G, Wollina U. Allergic maculopapular exanthema due to terbinafine. Open Access Maced J Med Sci. 2017;5(4):535-6.

24. Cohen PR, Erickson CP, Calame A. Terbinafineinduced lichenoid drug eruption: case report and review of terbinafine-associated cutaneous adverse events. Dermatol Online J. 202015;26(7):13030/qt9jh9p0xp.

25. Mayser P. Terbinafine: Drug-induced lupus erythematodes and triggering of psoriatic skin lesions. Hautarzt. 2016;67(9):724-31. German. 